\title{
Preventive Role of Gum Arabic Administration on STZ Induced Diabetic Kidney Disease in Rats; Renal Antioxidant and Histopathological Evidence
}

\author{
Función Preventiva de la Administración de Goma Arábiga en la Enfermedad Renal \\ Diabética Inducida por STZ en Ratas; Antioxidante Renal y Evidencia Histopatológica
}

Muataz E. Mohammed ${ }^{1}$; Rehab M. Badi' ${ }^{1,2}$; Osama M. Osman'; Mohamed D. Morsy ${ }^{1,3}$;

Amr M. Abbas ${ }^{1,4}$; Salah Omer Bashir ${ }^{1} \&$ Amal M. Saeed ${ }^{2}$

MUATAZ, E. M.; REHAB, M. B.; OSAMA, M. O.; MOHAMED, D. M.; AMR, M. A.; SALAH, O. B. \& AMAL, M. S. Preventive role of gum Arabic administration on STZ induced diabetic kidney disease in rats; renal antioxidant and histopathological evidences. Int. J. Morphol., 38(4):1003-1009, 2020.

SUMMARY: This study was set to investigate the effect of gum Arabic (G.A.) on diabetic kidney disease. We divided sixty male Sprague rats randomly into six groups. Normal control, normal rats treated with G.A., untreated diabetic rats, diabetic rats treated with insulin, diabetic rats treated with G.A., and diabetic rats treated with both insulin and G.A. Diabetes was induced by a single intraperitoneal injection of STZ. Forty eight hr post injections. Insulin was injected subcutaneously (1.6/IU/100g/day). We provided G.A. in drinking water (10 \%w/ v).). At the end of the twelve weeks, blood was drawn for measurement of blood glucose, glycosylated hemoglobin (HbA1C), serum lipids, serum creatinine, and blood urea. Renal tissue oxidative stress (O.S.) was assessed by measuring the activities of superoxide dismutase (SOD) and catalase (CAT), and the concentrations of reduced glutathione (GSH) and malondialdehyde (MDA). For histological assessments, sections from segments of kidneys were processed and stained with hematoxylin and eosin (H\&E) for assessment under the light microscope. STZinduced diabetes caused an elevation of blood glucose, HbA1c, urea and creatinine, triglycerides LDL and cholesterol, MDA with reduction of HDL, GSH level, and CAT and SOD activities. Histologically, kidneys from diabetic rats showed marked glomerular and tubular changes. Administration of G.A. alone to diabetic rats had a significant hypoglycemic, hypolipidemic, and antioxidant effect, although the levels achieved remained significantly abnormal compared with the untreated group with no effect on urea and creatinine levels. Co-administration of G.A. with insulin reversed the impact of D.M. on all parameters evaluated including the histological changes and led to normal urea and creatinine levels. We concluded that G.A., in combination with insulin, improves chemically-induced diabetes and its renal complications, possibly by modulation of oxidative stress.

KEY WORDS: Diabetes mellitus; Nephropathy; Gum Arabic; Oxidative stress.

\section{INTRODUCTION}

Diabetic kidney disease (DKD), which was formerly called diabetic nephropathy, is a common complication from diabetes. Approximately $20-40 \%$ of diabetic patients suffer from the condition (Gheith et al., 2016) which causes a progressive loss of renal function. These complications are due to the macro and microvascular changes because of hyperglycemia, hyperlipidemia, and oxidative stress (O.S.) (Cade, 2008). Oxidative stress results when the productions of reactive oxygen metabolites overcome the activity of the antioxidant defense system. There is continuous production of reactive oxygen species (ROS) such as superoxide (O2-), hydrogen peroxide ( $\mathrm{H} 2 \mathrm{O} 2)$, hydroxyl radical $(\mathrm{OH}-)$ as part of healthy cellular metabolism. The ROS function as messengers in multiple signalling pathways. Nevertheless, ROS can oxidize and hence damage macromolecules present in their vicinity, including proteins, carbohydrates, lipids, and DNA. A group of intracellular and extracellular antioxidant enzymes (AOEs) is tightly regulated to control the activity of ROS and maintain redox homeostasis. These enzymes include superoxide dismutase (SOD), glutathione peroxidase (GPx), glutathione reductase, catalase (CAT), hemoxygenase, and others (Dröge, 2002; Valko et al., 2007). The antioxidant

\footnotetext{
${ }^{1}$ Medical Physiology Department, College of Medicine, King Khalid University, KSA.

${ }^{2}$ Department of Physiology, Faculty of Medicine, Khartoum University, Sudan.

${ }^{3}$ Medical Physiology Department, College of Medicine, Menoufia University, Egypt.

${ }^{4}$ Medical Physiology Department, College of Medicine, Mansoura University, Egypt.

This work was supported by the Research Deanship of King Khalid University, Abha, Saudi Arabia; Grant number KKU Project Nº. R. G. P. 1/203/41.
} 
defense system also includes non-enzymatic antioxidant compounds such as glutathione (GSH), alpha-tocopherol (vitamin E), ascorbate (vitamin C), and Beta-carotene. Oxidative stress develops when the production of ROS exceeds its clearance by elements of the antioxidant defence system.

Over the years, it became clear that increased O.S. may lead to the development and progression of a vast number of diseases and disease-associated complications, including metabolic, degenerative, inflammatory, autoimmune and malignant diseases (Ghezzi et al., 2017). These discoveries were naturally paralleled by attempts to treat or prevent O.S. associated diseases through boosting the antioxidant defence system.

Both clinical and experimental studies suggest that O.S. occupies a central role in facilitating the development and progression of diabetic kidney disease (Miranda-Diaz et al., 2016). Based on the central part of O.S. in the pathogenesis of diabetic nephropathy, scientists investigated the potential use of antioxidants in the management of diabetic nephropathy.

Gum Arabic (G.A.) is a dried, gummy exudate obtained from the stems and branches of Acacia Senegal and A. Seyal. It is widely used in the food and pharmaceutical industries. The joint expert Committee for Food Additives (JECFA) confirmed its safety for human consumption (Phillips, 1998). Although GA was assumed to be an "inert" substance, during the last two decades, it became evident that G.A. has other actions, including an antioxidant effect (Calame et al., 2008; Ali et al., 2013; Nasir, 2013; Kaddam et al., 2017).

Our study aimed to investigate whether G.A. can serve as a nephron-protective dietary supplement in diabetic patients, and if this action involves improving diabetes mellitus induced O.S. in renal tissue. We used rats injected with streptozotocin as a model for diabetes.

\section{MATERIAL AND METHOD}

Sixty male Sprague-Dawley rats weighing 270 grams were included in this study. Rats were fed on a standard chow diet and had free access to drinking water or water containing GA $10 \%$ w/v when indicated. All procedures of animal handling were conducted according to the National Institute of Health's Guide for the Care and Use of Laboratory Animals.The Scientific Ethics Committee of King Khalid University approved the research protocol. We divided the rats into six groups of 10 rats each. The groups were as follows: Control group (C.N.): normal rats injected once intraperitoneally (I.P.) with freshly prepared citrate buffer. $(\mathrm{CN}+\mathrm{GA})$ group: normal rats received a single I.P. injection of citrate buffer and received G.A. in drinking water (10 $\%$ w/v) daily for 12 weeks. (D.M.) group: Diabetic rats that neither received insulin nor G.A. (DM+Ins) group: Diabetic rats administered a single daily dose of subcutaneous insulin $(1.6 / \mathrm{IU} / 100 \mathrm{~g})$. (DM+GA) group: Diabetic rats that received G.A. in drinking water $(10 \% \mathrm{w} / \mathrm{v})$. (DM+Ins+GA) group: Diabetic rats that received concomitant insulin and G.A.

Diabetes mellitus (IDDM) was induced by a single I.P. injection of streptozotocin STZ $(6.5 \mathrm{mg} / 100 \mathrm{~g})$ in freshly prepared citrate buffer (0.1 M, pH 4.5) (Sigma Chemical Company, USA). The control groups were injected once with the vehicle citrate buffer. D.M. was verified by measuring blood glucose in retro-orbital blood samples collected 48 hours following STZ injection. Rats with a non-fasting blood glucose level of $\geq 200 \mathrm{mmol} / \mathrm{L}$ were considered diabetic.

G.A. powder was purchased from Dar Savanna Sudan (http://www.darsavanna.net). G.A. was dissolved in tap water to obtain a solution of $10 \%$ w/v. G.A. solution was provided to rats as drinking water and was refreshed every 48 hours. The daily intake corresponded to a dose of approximately $20 \mathrm{~g} / \mathrm{kg}$ body weight /day

Insulin used in the study was Humulin 70/30 (70\% human insulin isophane suspension and $30 \%$ human soluble insulin injection [rDNA origin]). Insulin was given to rats subcutaneously in a single daily dose of $1.6 \mathrm{IU} / 100 \mathrm{Kg}$ body weight at 05:00 pm

At the end of the experiment (week 12), therats were anesthetized using diethyl ether. Venous blood samples were obtained from the tail, and then the rats were sacrificed by decapitation. Both kidneys were quickly removed, washed with phosphate-buffered saline (PBS), $\mathrm{pH} 7.4$, containing $0.16 \mathrm{mg} / \mathrm{ml}$ of heparin to remove any red blood cells and clots. Parts of the kidneys were homogenized with an ultrasonic homogenizer, the Omni tissue homogenizer (Omni International, Gainesville, VA). The supernatant was taken and stored frozen at $-40{ }^{\circ} \mathrm{C}$ until the time for determination of the renal levels of SOD, GSH, CAT, and MDA. The first three were used as markers for renal antioxidant activity and the last one as a marker for renal pro-oxidants.

Renal Homogenates (each ml contains 100mg of kidney tissue) were kept in separate tubes and stored at $-40^{\circ} \mathrm{C}$ and used later for biochemical analysis.

For histological assessments, small segments of kidneys were fixed in $10 \%$ buffered formalin and were processed for paraffin sectioning. Sections of about $5 \mathrm{~mm}$ 
width were stained with hematoxylin and eosin $(\mathrm{H} \& \mathrm{E})$ for assessment under the light microscope.

Blood glucose level, HbA1c, Blood urea level, serum creatinine level, total cholesterol, triglycerides, low-density lipoprotein (LDL), very-low-density lipoprotein (VLDL), and high-density lipoprotein (HDL) were all measured using standard biochemical methods with specific kits.

Where (T.G.)/5 is an estimate of VLDL-cholesterol, values are expressed in $\mathrm{mg} / \mathrm{dL}$.

Statistical analysis: Data were analyzed using SPSS version 22 (IBM). Values were expressed as mean \pm standard error of the mean (S.E.). Kruskal-Wallis test was used for multiple groups comparisons followed by the Man-Whitney U test for the comparison between two groups. P. values $<0.05$ were considered statistically significant.

\section{RESULTS}

Lipid profile. Untreated diabetic rats had significantly increased total cholesterol (CHL), TGRs, and LDL and reduced HDL levels compared to healthy controls (Table I). Rats in (DM+GA) group showed a significant reduction in CHL and TGR levels $(\mathrm{P}=0.004$ and 0.000 compared to (D.M.), but the new levels were still significantly higher than the normal control levels. Rats in (DM+Ins) group achieved normal levels of cholesterol and LDL. Rats in (DM+Ins+GA) group had normal levels of CHL, TGRs, LDL, and HDL.

Renal functions. Twelve weeks of G.A. supplementation did not affect serum urea and creatinine in normal control rats (Table I). Untreated diabetic rats had significantly increased blood urea and serum creatinine levels. Blood urea and serum creatinine in diabetic rats on either Insulin (DM+Ins) or G.A. (DM+GA) showed some reduction but were significantly higher compared to healthy controls.
Normal blood urea and serum creatinine were achieved in diabetic rats received insulin and gum Arabic (DM+Ins+GA).

Histopathology: (Fig. 1) Light microscopic pictures of renal tissues from control group (A) showed normal architecture of renal tissue, prominent Bowman's capsule, epithelial Cells and glomerular capillaries with normal tubular structures. Diabetic group (B) showed thickening of the basement membrane along with severe change in the density of mesenchyme, degeneration of glomerular capillaries, glomerular Hemorrhage with tubular dilation and necrosis. Insulin treated diabetic group (C) showed partial damaging of glomerular capillaries with less hemorrhage and the presence of injured dilated Bowman's capsule and less tubular dilation. Gum Arabic treated diabetic (D) group showed glomerular hypertrophy and partial damaging of glomerular capillaries with more hemorrhage and still damage of proximal and distal tubules than the insulin treated group. Gum Arabic and insulin treated diabetic group (E) showed normal kidney architecture in most of Bowman's capsules with intact epithelial cell and tubules structures and no hemorrhage

Indices of diabetes mellitus: (Fig. 2) Blood glucose levels: diabetic rats that received insulin alone $(\mathrm{DM}+\mathrm{Ins})$ or insulin and gum Arabic (DM+Ins+GA) were the only diabetic groups that had normal blood glucose at the end of week 12. HBA1c: Rats in (DM+ins) and (DM+GA) group had significantly lower levels of HbA1C compared to untreated diabetic rats $(\mathrm{P}=0.000)$, although the levels remained significantly higher when compared to the healthy controls $(\mathrm{P}=0.014,0.000$ respectively). Diabetic rats that received insulin and gum Arabic (DM+Ins+GA) group achieved normal levels of HbA1C.

Indices of renal oxidative stress (Fig. 3): The untreated diabetic group (D.M.) had significantly lower levels of the antioxidants SOD, CAT and GSH, and a higher level of the pro-oxidant MDA than the healthy control group (C.N.). Gum Arabic treatment for normal rats $(\mathrm{C}+\mathrm{GA})$ achieved a significant increase in the level of the antioxidant SOD and a significant reduction in the oxidant MDA.

Table I. The mean values \pm (SEM) of Lipid profile and renal function tests ( $n=10 /$ group).

\begin{tabular}{|c|c|c|c|c|c|c|}
\hline Category & Control & $\mathrm{C}+\mathrm{GA}$ & $\mathrm{DM}$ & $\mathrm{DM}+\mathrm{Ins}$ & $\mathrm{DM}+\mathrm{GA}$ & $\mathrm{DM}+\operatorname{Ins}+\mathrm{GA}$ \\
\hline Cholester ol (mg/dl) & $51.0 \pm 2.9$ & $35.1 \pm 1.3 \mathrm{a}$ & $92.8 \pm 6.6 \mathrm{ab}$ & $53.4 \pm 2.5 \mathrm{abc}$ & $66.9 \pm 2.5 \mathrm{abcd}$ & $47.8 \pm 1.6 \mathrm{ce}$ \\
\hline Triglycerides $(\mathrm{mg} / \mathrm{dl})$ & $56.9 \pm 4.7$ & $36.2 \pm 3.3 \mathrm{a}$ & $269.0 \pm 29.9 \mathrm{ab}$ & $96.1 \pm 12.6 \mathrm{abc}$ & $104.0 \pm 6.0 \mathrm{abc}$ & $74.8 \pm 10.3 \mathrm{abce}$ \\
\hline LDL (mg/dl & $5.5 \pm 2.3$ & $7.4 \pm 0.12$ & $24.6 \pm 3.7 \mathrm{ab}$ & $13.4 \pm 2.7 \mathrm{a}$ & $21.9 \pm 1.3 \mathrm{ab}$ & $10.4 \pm 1.8 \mathrm{ce}$ \\
\hline HDL (mg/dl) & $30.3 \pm 2.8$ & $30.9 \pm 2.0$ & $16.9 \pm 1.7 \mathrm{ab}$ & $20.7 \pm 1.6 \mathrm{ab}$ & $20.2 \pm 0.75 \mathrm{ab}$ & $26.2 \pm 1.5 \mathrm{cde}$ \\
\hline Urea (mg/dl) & $25.0 \pm 1.8$ & $30.2 \pm 2.0$ & $106.4 \pm 5.9 \mathrm{ab}$ & $52.3 \pm 2.4 \mathrm{abc}$ & $87.5 \pm 9.1 \mathrm{abd}$ & $34.4 \pm 3.6 \mathrm{cde}$ \\
\hline Creatinine (mg/dl) & $0.6 \pm 0.03$ & $0.5 \pm 0.02$ & $1.0 \pm 0.11 \mathrm{ab}$ & $0.9 \pm 0.1 \mathrm{ab}$ & $0.8 \pm 0.03 \mathrm{ab}$ & $0.6 \pm 0.04 \mathrm{cde}$ \\
\hline
\end{tabular}

$\mathrm{C}+\mathrm{GA}=\mathrm{Control}$ treated with gum arabic, $\mathrm{DM}=$ diabetic non-treated, $\mathrm{DM}+\mathrm{Ins}=$ Diabetic treated with insulin, $\mathrm{DM}+\mathrm{GA}=$ diabetic treated with $\mathrm{Gum}$ Arabic, DM+Ins+GA= diabetic treated with insulin and Gum Arabic. a: significant compared with control group, b: significant compared with C+GA group, c: significant with DM group, d: significant compared with DM + Ins group e: significant compared with DM + GA group. P. values $<0.05$ were considered statistically significant. 

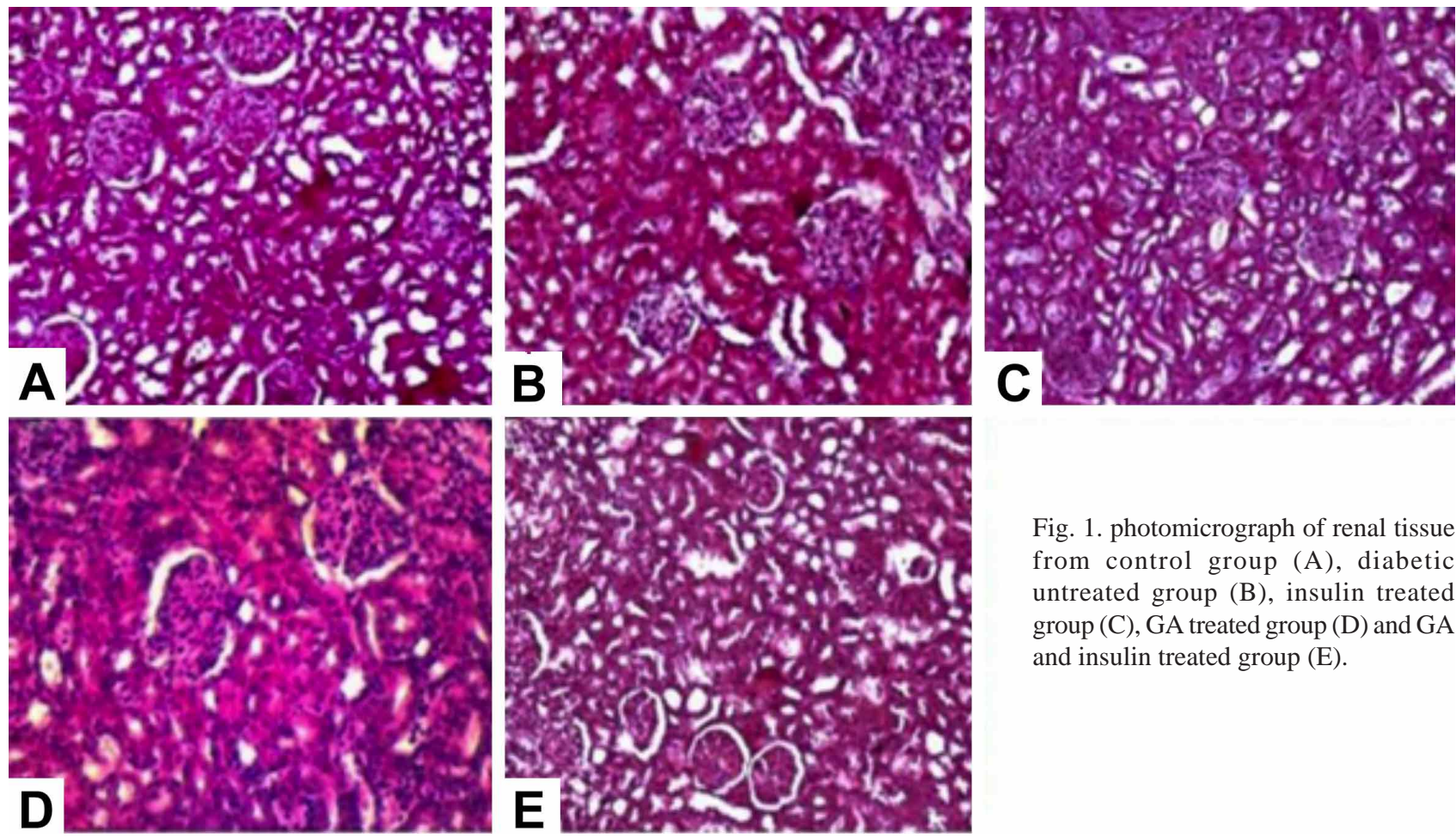

Fig. 1. photomicrograph of renal tissue from control group (A), diabetic untreated group (B), insulin treated group (C), GA treated group (D) and GA and insulin treated group $(\mathrm{E})$.
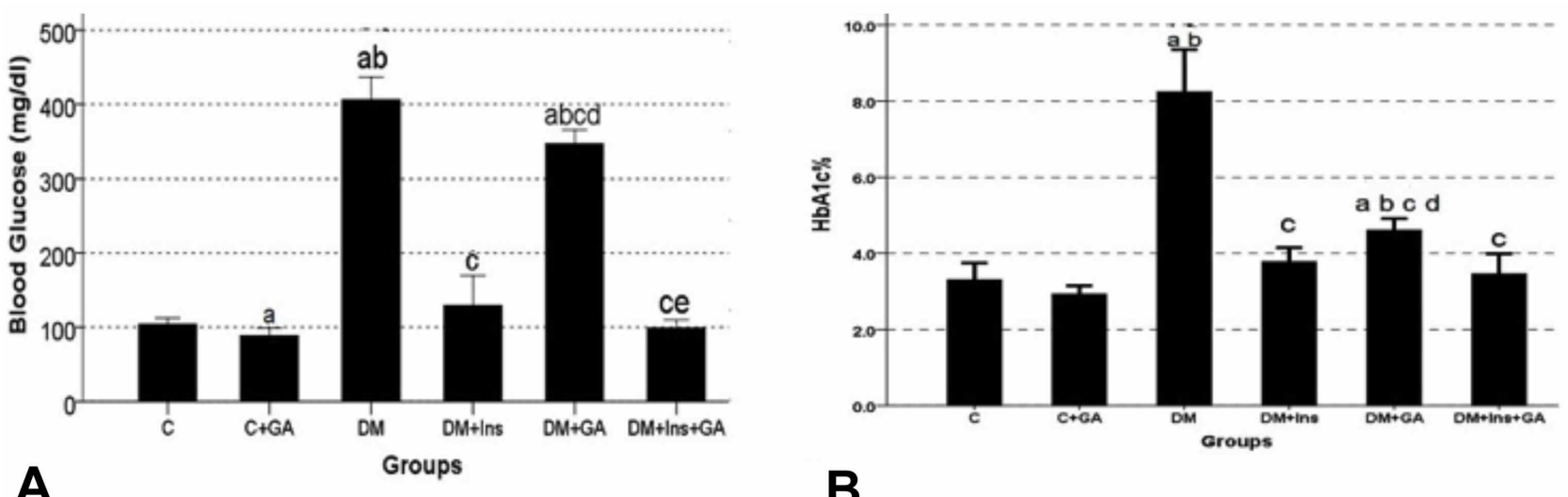

B

Fig. 2. The mean values \pm (SEM) of blood glucose (A) and HbA1c (B) ( $\mathrm{n}=10$ /group).

$\mathrm{C}$ : control group, $\mathrm{C}+\mathrm{GA}=$ normal control on GA, DM: untreated diabetic group; DM+Ins+ Diabetics on insulin; DM+GA: Diabetics on GA; DM+Ins+GA: Diabetics on insulin and GA. a: significant compared with control group, b: significant compared with C+GA group, c: significant with DM group, d: significant compared with DM + Ins group e: significant compared with DM + GA group. P. values < 0.05 were considered statistically significant.

SOD: All treated D.M. groups (DM+Ins, DM+GA, and DM+Ins+GA) had significantly higher renal SOD activity in comparison to the untreated D.M. group. However, SOD activity was still significantly lower compared to the healthy control group. CAT: CAT activity in the renal homogenates of all four diabetic groups was significantly reduced compared with the healthy control group. The three treated
D.M. groups; (DM+Ins), (DM+GA) and (DM+Ins+GA) were found to have significantly higher CAT activity compared to the untreated D.M. group.The (DM+Ins+GA) group had significantly increased renal homogenate CAT activity than the groups that received insulin (DM+Ins) or gum arabic alone( $\mathrm{DM}+\mathrm{GA})$. GSH: The three treated diabetic groups (DM+Ins, $\mathrm{DM}+\mathrm{GA}, \mathrm{DM}+\mathrm{Ins}+\mathrm{GA}$ ) achieved significant increases in 

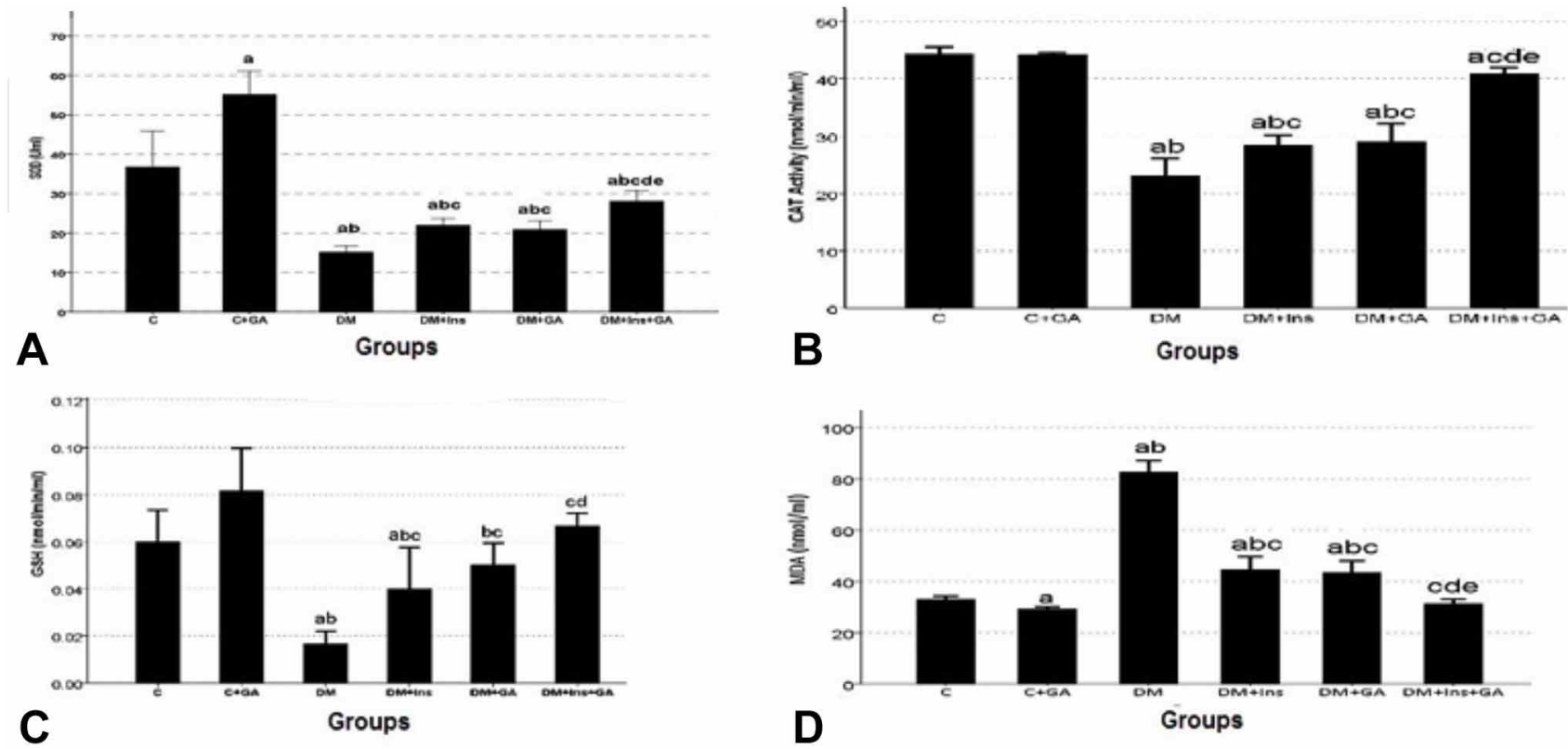

Fig. 3. mean values \pm (SEM) of the activity of superoxide dismutase (SOD) (A), and levels of Catalase (CAT) (B), Glutathione (GSH) (C) and malondialdehyde (MDA) (D) in the renal homogenates of all groups ( $n=10$ /group). C: control; C+GA: control+GA; DM: diabetes mellitus; DM+Ins: diabetes mellitus+insulin; DM+GA: diabetes mellitus+gum Arabic; DM+Ins+GA: diabetes mellitus+insulin +gum Arabic. a: significant compared with control group, b: significant compared with C+GA group, c: significant with DM group, d: significant compared with DM + Ins group e: significant compared with DM + GA group. P. values $<0.05$ were considered statistically significant.

GSH levels compared to untreated D.M. group. The GSH levels in therenal homogenates of rats in $(\mathrm{DM}+\mathrm{Ins}+\mathrm{GA})$ group were significantly higher by $50 \%$ compared to rats in (DM+Ins) group ( $\mathrm{P}=0.003)$. Renal-GSH activity in (DM+Ins) group was similar to GSH activity in (DM+GA) group. Renal-GSH level in diabetic rats in (DM+Ins+GA) group was within the normal range. MDA: MDA levels were significantly lower in $(\mathrm{DM}+\mathrm{Ins}),(\mathrm{DM}+\mathrm{GA})$, and $(\mathrm{DM}+\mathrm{Ins}+\mathrm{GA})$ groups. MDA levels reported in (DM+GA) group were similar to MDA levels reported in $(\mathrm{DM}+\mathrm{Ins})$ group. Renal tissue MDA level in (DM+Ins+GA) group was $30 \%$ less than in (DM+Ins) group $(\mathrm{P}=0.004)$ and was similar to levels reported in the healthy untreated control rats.

\section{DISCUSSION}

Diabetic kidney disease (DKD) is the most common reason for progressing to end-stage renal disease and is the single strongest predictor of mortality in patients with diabetes (Reidy et al., 2014). In this study, we evaluated the effects of gum Arabic (G.A.) in the development of DKD on STZinduced diabetes in rats. G.A. was used in this study because it was found to have an antioxidant property (Ali et al., 2009). Moreover, gum Arabic was found to be safe for humans' consumption and does not change the food properties.
This study observed that the induction of diabetes in our experimental rats led to the development of DKD, as evidenced by the significant rise in both creatinine and urea levels. The untreated diabetic rats also showed significant hyperglycemia, dyslipidemia, and increased oxidative stress. These factors contribute to the development of DKD, as suggested by previous studies (Reidy et al.). Our light microscopic investigations confirmed the development of DKD (Fig. 3). Targeting these abnormalities may lead to the prevention of the development of DKD.

The results of the present study indicated that the administration of G.A. to STZ induced diabetes in rats significantly improved the adverse metabolic effects of diabetes and protected against the development of DKD. G.A. treatment resulted in better glycemic control, improved lipid profile, as well as oxidative stress markers, compared with untreated diabetic rats. However, normalization of the renal functions in diabetic rats was only observed on rats that received concomitant administration of G.A. and insulin. The histopathological changes observed in the diabetic group were partially improved by either administration of insulin or GA alone. Complete reversal of the pathological changes was seen only in kidney tissues from diabetic rats that received concomitant administration of insulin and GA.

Oxidative stress is the common link for the major 
pathways involved in the development and progression of diabetic micro and macrovascular complications of diabetes (Kashihara et al., 2010). The increased O.S. in renal tissue can disturb cellular function through inducing conformational changes in proteins, lipids, carbohydrates, and DNA. Furthermore, ROS promotes pro-inflammatory and pro-fibrotic responses in renal tissue by activatingredoxsensitive pathways that lead to the structural changes characteristic of DKD (Lee et al., 2003). Induction of diabetes in our study increased oxidative stress as marked by the high MDA and decreased GSH, CAT, and SOD levels. Therefore, it was not surprising that the untreated diabetic rats in the current study developed reduced renal function during the 12 weeks of the experiment, as evidenced by the elevated levels of their blood urea and serum creatinine.

G.A. administration ameliorated the oxidative stress in all diabetic and healthy control rats. Different ways may have produced the antioxidant effect of G.A. in our study; a direct antioxidant, hypoglycemic effect, and lipid-lowering effect. G.A. was reported to have a direct antioxidant effect. It protected the kidneys from the nephrotoxic effect of gentamicin and mercuric chloride, two agents known to induce renal damage through increased O.S mechanisms (AlMajed et al., 2002; Gado \& Aldahmash, 2013). In addition, G.A. treatment significantly reduced the production of superoxide radicals and increased renal GSH content and SOD activity in rats with adenine induced chronic renal failure (Ali et al., 2013). In this study, we detected the antioxidant activity of G.A. in the renal tissues of normal control rats, where G.A. treatment significantly increased SOD activity and reduced lipid peroxidation in the renal homogenates. This effect was independent of changes in blood glucose.

Hyperglycemia is a major cause of increased O.S. in diabetes. The level of lipid peroxidation products such as MDA was directly related to the level of hyperglycemia (Manohar et al., 2013). Chronic hyperglycemia promotes the progression of cell injury and end-stage renal disease by triggering oxidative stress and inflammation (Amorim et al., 2019). Our study confirmed the hypoglycemic effect of G.A. reported by Babiker et al. (2017). G.A. administration improved glycemic control in our diabetic rats but remained significantly higher than the healthy control group.

Either isolated G.A. or insulin treatment caused a significant improvement in the redox status of the diabetic kidney. Both methods significantly increased SOD and CAT activities, increased GSH level, and reduced MDA concentrations in the renal homogenates of diabetic rats. Interestingly, both ways had equal efficiency in achieving these changes. Nevertheless, it is essential to point out that in insulin treated-rats, blood glucose level was normal, but G.A. -treated rats still suffered from hyperglycemia and had increased $\mathrm{HbA} 1 \mathrm{C}$ levels. This observation, together with the fact that G.A. improved renal redox status in the healthy kidney, supports that the G.A. antioxidant effect in diabetes was not very dependent on controlling glucose concentration and involve different mechanisms than that of insulin. Therefore, the antioxidant effect of G.A. and insulin can act synergistically to reduce O.S. in renal tissue. Indeed, when G.A. was co-administered with insulin, renal tissue MDA concentration decreased by $30 \%$ compared to its level in the renal homogenates of diabetic rats on isolated insulin treatment. Also, there was a $28.3 \%$ increase in SOD activity, a $43.5 \%$ increase in CAT activity, and a $50 \%$ increase in GSH level.

Studies have shown that hyperlipidemia increases the plasma levels of oxygen free radicals by reacting with lipids, proteins, and DNA to produce oxidized compounds, such as MDA (Prasad \& Kalra, 1993).In hyper-cholesterolemic rabbits, oxidative stress was reduced by lipid lowering based on dietary intervention in the absence of drugs (Yang et al., 2008). Many polyphenolic compounds possess hypolipidemic activity. They have been shown to increase the fecal fat excretion and LDL receptor activity (Boruah $e t$ al., 2014). G. A. is a phenolic compound, which may also possess the same hypolipidemic action. Mohamed et al. (2015) documented a lowering effect of G.A. in hyperlipidemic patients. Our study supports this hypolipidemic effect of GA. Administration of G.A. to normal rats produced a significant lowering of T.G. and cholesterol. The same result was observed in the diabetic group treated with G.A. alone, but still, levels were higher than the healthy control group. However, the combined treatment with G.A. and insulin to diabetic rats achieved a healthy lipid profile. This favorable effect of G.A. on the lipid profile may have contributed to the reduction in the state of O.S. in the experimental rats.

In summary, the G.A. administration ameliorated the oxidative stress in diabetic rats. This effect may be through a direct antioxidant effect, the hypolipidemic effect, or a hypoglycemic effect. Adjunct administration of G.A. with insulin led to normalization of the metabolic effects associated with diabetes, namely hyperglycemia, dyslipidemia, and oxidative stress, and protects against the development of DKD.The contribution of each of these factors need more detailed studies.

In conclusion, given the safety of G.A., we recommend it to be added as a dietary supplement early on to diabetic patients. The long-term nephron-protective effects of G.A. administration needs to be studied. 
MUATAZ, E. M.; REHAB, M. B.; OSAMA, M. O.; MOHAMED, D. M.; AMR, M. A.; SALAH, O. B. \& AMAL, M.S. Función preventiva de la administración de goma arábiga en la enfermedad renal diabética inducida por STZ en ratas; antioxidante renal y evidencia histopatológica. Int. J. Morphol., 38(4):1003-1009, 2020.

RESUMEN: En este estudio se evaluó el efecto de la goma arábiga (GA) en la enfermedad renal diabética. Dividimos sesenta ratas macho Sprague Dawley al azar en seis grupos. Control normal, ratas normales tratadas con GA, ratas diabéticas no tratadas, ratas diabéticas tratadas con insulina, ratas diabéticas tratadas con GA y ratas diabéticas tratadas con insulina y GA. La diabetes fue inducida por una sola inyección intraperitoneal de STZ. Cuarenta y ocho horas después se inyectó insulina por vía subcutánea (1,6 / UI / $100 \mathrm{~g} /$ día). A los animales se les dió GA en agua potable (10 $\% \mathrm{p} / \mathrm{v})$ ). Al final de las doce semanas, se extrajo sangre para medir la glucosa, la hemoglobina glicosilada (HbA1C), los lípidos en suero, la creatinina en suero y la urea en sangre. El estrés oxidativo del tejido renal (SO) se evaluó midiendo las actividades de la enzima superóxido dismutasa (SOD) y la catalasa (CAT), y las concentraciones de glutatión reducido (GSH) y malondialdehído (MDA). Para las evaluaciones histológicas, se procesaron secciones de segmentos de riñones y se tiñeron con hematoxilina y eosina (H \& E) para análisis bajo microscopio óptico. La diabetes inducida por STZ causó una elevación de la glucosa en sangre, HbA1c, urea y creatinina, triglicéridos LDL y colesterol, MDA con reducción de las actividades de HDL, GSH y CAT y SOD. Histológicamente, los riñones de ratas diabéticas mostraron marcados cambios glomerulares y tubulares. La administración de GA solo en las ratas diabéticas tuvo un efecto hipoglucémico, hipolipidémico y antioxidante significativo, aunque los niveles alcanzados permanecieron significativamente anormales en comparación con el grupo no tratado, sin ningún efecto sobre los niveles de urea y creatinina. La dministración conjunta de GA con insulina revirtió el impacto de DM en todos los parámetros evaluados, incluidos los cambios histológicos y condujeron a niveles normales de urea y creatinina. Concluimos que GA en combinación con insulina, mejora la diabetes inducida químicamente y sus complicaciones renales, posiblemente mediante la modulación del estrés oxidativo.

PALABRAS CLAVE: Diabetes mellitus; Nefropatía; Goma Arábiga; Estrés oxidativo.

\section{REFERENCES}

Al-Majed, A. A.; Mostafa, A. M.; Al-Rikabi, A. C. \& Al-Shabanah, O. A. Protective effects of oral arabic gum administration on gentamicin-induced nephrotoxicity in rats. Pharmacol. Res., 46(5):445-51, 2002.

Ali, B. H.; Al-Husseni, I.; Beegam, S.; Al-Shukaili, A.; Nemmar, A.; Schierling, S.; Queisser, N. \& Schupp, N. Effect of gum arabic on oxidative stress and inflammation in adenine-induced chronic renal failure in rats. PLoS One, 8(2):e55242, 2013

Ali, B. H.; Ziada, A. \& Blunden, G. Biological effects of gum arabic: a review of some recent research. Food Chem. Toxicol., 47(1):1-8, 2009.

Amorim, R. G.; Guedes, G. D. S.; Vasconcelos, S. M. L. \& Santos, J. C. F. Kidney disease in diabetes mellitus: cross-linking between hyperglycemia, redox imbalance and inflammation. Arq. Bras. Cardiol., 112 (5):577-87, 2019.

Boruah, D. C.; Devi, R.; Tamuli, S.; Kotoky, J. \& Sharma, D. K. Hypolipidemic activity of crude polyphenols from the leaves of Clerodendron colebrookianum Walp in cholesterol fed rats. J. Food Sci. Technol., 51(11):3333-40, 2014.

Cade, W. T. Diabetes-related microvascular and macrovascular diseases in the physical therapy setting. Phys. Ther., 88(11):1322-35, 2008.

Calame, W.; Weseler, A. R.; Viebke, C.; Flynn, C. \& Siemensma, A. D. Gum arabic establishes prebiotic functionality in healthy human volunteers in a dose-dependent manner. Br. J. Nutr., 100(6):1269-75, 2008.

Dröge, W. Free radicals in the physiological control of cell function. Physiol. Rev., 82(1):47-95, 2002

Gado, A. M. \& Aldahmash, B. A. Antioxidant effect of Arabic gum against mercuric chloride-induced nephrotoxicity. Drug Des. Devel. Ther., 7:1245$52,2013$.

Gheith, O.; Farouk, N.; Nampoory, N.; Halim, M. A. \& Al-Otaibi, T. Diabetic kidney disease: world wide difference of prevalence and risk factors. $J$. Nephropharmacol., 5(1):49-56, 2016.

Ghezzi, P.; Jaquet, V.; Marcucci, F. \& Schmidt, H. H. H. W. The oxidative stress theory of disease: levels of evidence and epistemological aspects. $\mathrm{Br} . J$. Pharmacol., 174(12):1784-96, 2017.

Kaddam, L.; Fadl-Elmula, I.; Eisawi, O. A.; Abdelrazig, H. A.; Salih, M. A.; Lang, F. \& Saeed, A. M. Gum Arabic as novel anti-oxidant agent in sickle cell anemia, phase II trial. BMC Hematol., 17:4, 2017.

Kashihara, N.; Haruna, Y.; Kondeti, V. K. \& Kanwar, Y. S. Oxidative stress in diabetic nephropathy. Curr. Med. Chem., 17(34):4256-69, 2010.

Lee, H. B.; Yu, M. R.; Yang, Y.; Jiang, Z. \& Ha, H. Reactive oxygen speciesregulated signaling pathways in diabetic nephropathy. J. Am. Soc. Nephrol., 14(8 Suppl. 3):S241-5, 2003.

Manohar, S. M.; Vaikasuvu, S. R.: Deepthi, K.; Sachan, A. \& Narasimha, S. R. An association of hyperglycemia with plasma malondialdehyde and atherogenic lipid risk factors in newly diagnosed Type 2 diabetic patients. $J$. Res. Med. Sci., 18(2):89-93, 2013.

Miranda-Diaz, A. G.; Pazarín-Villaseñor, L.; Yanowsky-Escatell, F. G. \& AndradeSierra, J. Oxidative stress in diabetic nephropathy with early chronic kidney disease. J. Diabetes Res., 2016:7047238, 2016.

Nasir, O. Renal and extrarenal effects of gum arabic ( Acacia senegal )--what can be learned from animal experiments? Kidney Blood Press. Res., 37(4-5):26979, 2013.

Phillips, G. O. Acacia gum (Gum Arabic): a nutritional fibre; metabolism and calorific value. Food Addit. Contam., 15(3):251-64,1998.

Prasad, K. \& Kalra, J. Oxygen free radicals and hypercholesterolemic atherosclerosis: effect of vitamin E. Am. Heart J., 125(4):958-73, 1993.

Reidy, K.; Kang, H. M.; Hostetter, T. \& Susztak, K. Molecular mechanisms of diabetic kidney disease. J. Clin. Invest., 124(6):2333-40, 2014.

Valko, M., Leibfritz, D., Moncol, J., Cronin, M. T., Mazur, M., \& Telser, J. Free radicals and antioxidants in normal physiological functions and human disease. Int. J. Biochem. Cell Biol., 39(1):44-84, 2007.

Yang, R. L.; Shi, Y. H.; Hao, G.; Li, W. \& Le, G. W. Increasing oxidative stress with progressive hyperlipidemia in human: relation between malondialdehyde and atherogenic index. J. Clin. Biochem. Nutr., 43(3):154-8, 2008.

\section{Corresponding author:}

Osama M. Osman

Department of Physiology

College of Medicine

King Khalid University.

Abha, KSA

SAUDI ARABIA

\section{E-mail: osama_elneel@yahoo.com}

Received: $17-02-2020$

Accepted: $20-03-2020$ 